\title{
Studi Kasus Perawatan Luka dengan Gel Aloe Vera pada Pasien Ulkus kaki Diabetik
}

\author{
Yance Komela Sari $^{1}$, Hema Malini², Elvi Oktarina ${ }^{2}$
}

\begin{abstract}
Abstrak
Diabetes melitus dapat menyebabkan komplikasi ulkus kaki diabetik. Perawatan luka yang tepat dapat dilakukan untuk mencegah terjadinya amputasi yaitu perawatan luka moist dengan menggunakan gel aloe vera. Dilaporkan seorang wanita 55 tahun mengalami ulkus kaki diabetik setelah luka tidak sembuh-sembuh dalam waktu yang lama. Pengkajian luka menggunakan Bates-Jensen Wound Assessment Tool dan luka dinilai setiap minggu selama 3 minggu. Hasil dari penjumlahan Bates Jensen pada saat pre-test 45, post-test pertama 40, post-test kedua 34 dan post-test ketiga 26. Pasien diberikan perawatan luka setiap dua hari sekali dengan menggunakan gel aloe vera selama 3 minggu dan mengalami perbaikan secara signifikan. Perawatan luka dengan gel aloe vera efektif pada kasus ini.
\end{abstract}

Kata kunci: Bates-Jensen Wound Assessment Tool, gel aloe vera, ulkus kaki diabetes

\begin{abstract}
Diabetes mellitus can lead to complications of diabetic foot ulcers. Proper wound care can be taken to prevent amputation is moist wound treatment using aloe vera gel. It was reported a women 55 years of experience diabetic foot ulcer after the wound does not heal in a long time. Assessment used Bates-Jensen Wound Assessment Tool and injury assessed every week for 3 weeks. The results from the sum Bates Jensen during pre-test 45, the first 40 posttest, the both post-test 34 and post-test the third 26. The wound care patient is given once every 2 days using aloe vera gel for 3 weeks and significantly improved. Wound care with aloe vera gel is effective in this case.
\end{abstract}

Keywords: aloe vera gel, Bates Jensen wound assessment tool, diabetic foot ulcer

Affiliasi penulis: 1. Prodi Magister Keperawatan, Universitas Andalas, Padang, Indonesia. 2. Fakultas Keperawatan, Universitas Andalas, Padang, Indonesia.

Korespondensi: Hema Malini. Email:hemamalini@nrs.unand.ac.id Telp.: 085374179586

\section{PENDAHULUAN}

Ulkus kaki diabetik merupakan komplikasi makrovaskular dari diabetes yang diakibatkan karena terjadinya neuropati perifer. ${ }^{1}$ Ulkus kaki diabetik terjadi pada $15 \%$ pasien diabetes. ${ }^{2}$ Dimana pasien diabetes memiliki resiko terjadinya amputasi ekstremitas bawah 15 hingga 40 kali lebih tinggi jika dibandingkan dengan pasien tanpa diabetes. ${ }^{3}$

Angka kejadian amputasi pada pasien ulkus kaki diabetik sebesar $85 \%{ }^{2}$ Kejadian amputasi minor sebesar $80,6 \%$ dan amputasi mayor $18,4 \%$ yang disebabkan karena infeksi $50,8 \%$ dan gangren. ${ }^{4}$ Salah satu cara untuk mencegah agar amputasi tidak terjadi adalah dengan perawatan luka. ${ }^{5}$ Perawatan luka saat ini sudah berkembang pesat dari prinsip dry menjadi prinsip moist. ${ }^{6}$

Perawatan luka prinsip dry tidak digunakan lagi karena dapat menimbulkan infeksi dan memperlambat penyembuhan. ${ }^{7}$ Tingkat infeksi pada perawatan luka dengan prinsip dry lebih tinggi dibandingkan prinsip moist. ${ }^{6}$ Salah satu prinsip moist yang dapat digunakan untuk perawatan luka adalah gel aloe vera. ${ }^{8}$

Aloe vera adalah salah satu tanaman obat yang banyak manfaatnya. ${ }^{9}$ Pada zaman dahulu sejak 2000 tahun yang lalu masyarakat Cina, Mesir, Yunani, India, 
Meksiko, Jepang telah menggunakan aloe vera untuk kesehatan, kecantikan, obat dan perawatan kulit seperti mengobati prajurit yang terluka, luka bakar, membasmi racun pada tubuh, mengobati demam, melancarkan buang air besar dan menyembuhkan luka pada penderita lepra dan masalah kesehatan lainnya. ${ }^{10}$ Aloe vera juga digunakan untuk mengobati dermatitis dan penyakit kulit lainnya pada pertengahan 1930-an. ${ }^{11}$

Gel aloe vera mengandung kadar air yang tinggi, mannosa 6-fosfat, acemannan, saponin yang dapat mempertahankan kelembaban luka, meningkatkan migrasi sel epitel, menstimulasi makrofag, fibroblas, jaringan granulasi sehingga mempercepat penyembuhan luka. Gel aloe vera dapat mencegah terjadinya iskemia karena dapat menghambat tromboksan A2. ${ }^{12}$

Hasil literatur review menunjukan gel aloe vera bermanfaat untuk mempercepat proses penyembuhan luka seperti luka bakar, luka op seksio cesarea dan luka kronik. ${ }^{13}$ Perawatan luka luka ulkus kaki diabetik dengan menggunakan gel aloe vera belum banyak dipublikasikan.

\section{KASUS}

Seorang wanita berumur 55 tahun di wilayah kerja puskesamas kota Padang mengalami ulkus kaki diabetik pada ekstremitas kanan bawah. Pasien diberikan perawatan luka dirumah dengan menggunakan gel aloe vera setiap 2 hari sekali selama 3 minggu. Penilaian luka dilakukan sebanyak 4 kali yaitu sebelum perawatan dan setiap minggu setelah perawatan luka. Pada saat dilakukan pengkajian pada tanggal 4 Maret 2019 Klien mengatakan luka yang dialaminya sudah lebih dari 3 bulan. Klien tidak mengetahui penyebab terjadinya luka pada kakinya. Klien juga tidak nafsu makan. Klien baru mengetahui menderita penyakit diabetes setelah terjadi luka pada kakinya. Pada saat itu klien memeriksakan diri ke pelayanan kesehatan karena luka pada kakinya tidak sembuh-sembuh. Hasil gula darah klien 396 mg/dL.

Klien tidak mempunyai penyakit keturunan diabetes. Klien juga tidak merokok. Hasil pemeriksaan fisik terdapat ulkus pada ekstremitas kanan bawah, ulkus berbau. Pengkajian wound status continuum menggunakan Bates-Jensen Wound Assessment Tool yang terdiri dari 13 item penilaian. ${ }^{14}$ Ukuran luka $\mathrm{PX}$ L $16<36 \mathrm{~cm}$, Kedalaman stage 2 (kerusakan partial thickness skin yang melibatkan epidermis atau dermis, tepi luka jelas, tidak menyatu dgn dasar luka, tidak terdapat goa (undermaning), tipe jaringan nekrosis lengket, lembut dan ada jaringan parut palsu berwarna hitam (black eschar), jumlah jaringan nekrosis 75\% hingga $100 \%$ dari dasar luka, tipe eksudate purulent, jumlah eksudate sedang (jaringan luka jenuh; terdapat $>25 \%$ hingga $\leq 75 \%$ eksudat pada balutan/ dressing. Warna kulit sekitar luka putih atau pucat atau hipopigmentasi, jaringan yang edema non pitting edema kurang dari $<4 \mathrm{~cm}$ disekitar luka, pengerasan jaringan tepi pengerasan $2-4 \mathrm{~cm}$ menyebar $<50 \%$ di tepi luka, jaringan granulasi tidak ada jaringan granulasi, epitelisasi $<25 \%$ epitelisasi. Hasil dari penjumlahan Bates Jensen pre-test adalah 45 . Setelah dilakukan perawatan luka selama 3 minggu terdapat penurunan jumlah skor Bates Jensen yaitu post-test pertama 40, post test kedua 34 dan post-test ketiga 26.

Hasil pemeriksaan pre-test gula darah dan hemoglobin dengan menggunakan alat Easy Touch Multi Chect didapatkan hasil Gula Darah Sewaktu (GDS): $236 \mathrm{mg} / \mathrm{dL}, \mathrm{Hb}:$ 10,5 g/dl. Pada minggu pertama GDS: $295 \mathrm{mg} / \mathrm{dL}, \mathrm{Hb}: 12,5 \mathrm{~g} / \mathrm{dl}$. Pada minggu kedua GDS: $195 \mathrm{mg} / \mathrm{dL}, \mathrm{Hb}: 12,7 \mathrm{~g} / \mathrm{dl}$ dan minggu ketiga GDS: 150 mg/dL, Hb: 12,9g/dl . Selama ini klien melakukan perawatan luka dirumah setiap 1-3 kali sehari dengan menggunakan cairan $\mathrm{H} 2 \mathrm{O}$ dan $\mathrm{NaCl}$ 0.9\%. Kondisi luka klien sangat berbau.

Berdasarkan pengkajian yang telah dilakukan maka diagnosa keperawatan yang muncul adalah kerusakan integritas kulit dan resiko infeksi. Adapun rencana keperawatan yang akan dilakukan adalah TIME manajemen yaitu Tissue manajement; Inflamation and infection contol; Moisture balance dan Epithelial advancement/edge. ${ }^{15}$ Tissue manajement adalah melakukan autolisis debridement dengan menggunakan gel aloe vera. Tujuan dari autolisis ini untuk mendapatkan dasar luka berwarna merah. Inflamation and infection contol dilakukan dengan cara mencuci luka dengan sabun gentle antiseptik. 
Moisture balance yaitu proses proliferasi yang memerlukan suasana lembab yang seimbang dengan menggunakan dressing.

Dressing terbagi dua yaitu dressing primer dan dressing sekunder. Dressing primer adalah dressing yang langsung kontak ke luka sedangkan dressing sekunder digunakan untuk menutupi dressing primer. ${ }^{16}$ Dressing primer yang yang digunakan pada kasus ini adalah gel aloe vera. Dressing sekunder menggunakan island dressing dan kassa. Luka difiksasi dengan menggunakan crape bandage. Island dressing merupakan penutup luka yang nyaman dan tidak menimbulkan trauma saat balutan luka dibuka, selain itu dapat menyerap cairan dan tidak ada menimbukan reaksi sensitivitas atau pada iritasi jaringan luka. ${ }^{17}$ Rencana yang akan dilakukan adalah support nutrisi, massage ringan disekitar luka dan kontrol gula darah.

Implementasi keperawatan yang dilakukan adalah, Pertama; mencuci luka dengan sabun gentle antiseptik. Kedua; melakukan tissue manajemen dengan cara autolisis menggunakan gel aloe vera. Ketiga; menutup luka dengan menggunakan island dressing dan kassa. Keempat; melakukan fiksasi dengan menggunakan crape bandage. Kelima; perban diganti setiap 2 hari sekali dan penilaian luka dilakukan setiap satu minggu perawatan luka yaitu minggu ke-1, minggu ke-2 dan minggu ke-3.

Setelah dilakukan perawatan luka, terjadi penurunan rata-rata jumlah skor Bates Jensen. Pada minggu pertama skor menjadi 40, minggu ke-2 34 dan minggu ke-3 26. Perkembangan luka dapat dilihat pada gambar 1 berikut ini.
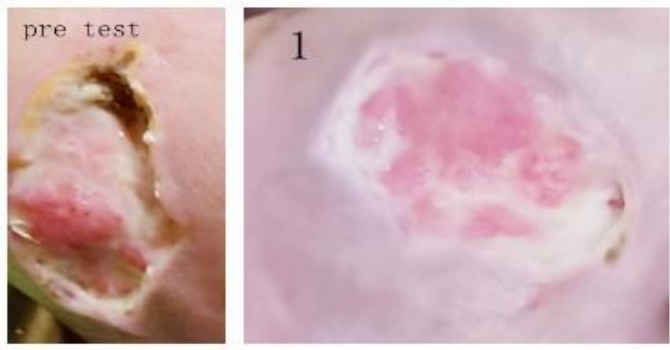

Gambar 1: Pre-test minggu pertama
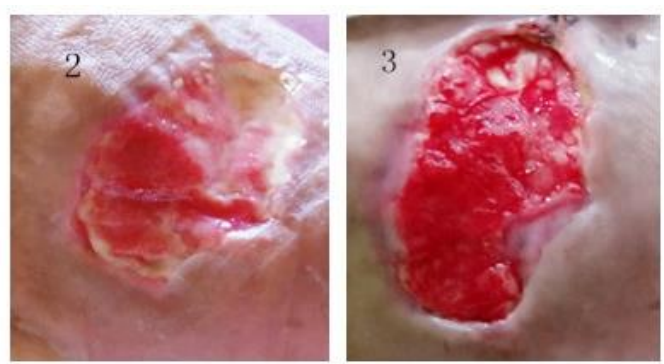

Gambar 2: minggu kedua dan minggu ketiga.

\section{PEMBAHASAN}

Hasil pengukuran Bates Jensen menunjukan gel aloe vera dapat menurunkan skor Bates Jensen wound status continuum dalam kasus ini. Dari 13 item wound status continuum Bates Jensen yang menunjukan perubahan setelah melakukan perawatan luka selama 3 minggu dengan gel aloe vera setiap 2 hari sekali adalah tipe jaringan nekrosis, jumlah jaringan nekrosis, tipe eksudat, jumlah eksudat, jaringan yang edema, pengerasan jaringan tepi, jaringan granulasi dan epitelisasi.

Dalam kasus ini menunjukan perubahan wound status continuum yang signifikan. Menurut analisis peneliti, terjadinya perubahan yang signifikan pada kasus ini karena disebabkan perawatan luka dengan menggunakan gel aloe vera. Perubahan luka pada kasus ini sejalan dengan kasus yang ditangani oleh Avijgan et al, setelah dilakukan perawatan pada pasien luka bakar dengan menggunakan gel aloe vera didapatkan perubahan yang signifikan. ${ }^{18}$ Dimana jaringan granulasi berkembang pesat, pasien tidak alergi dan tidak ada infeksi sehingga proses penyembuhan luka menjadi cepat. Penelitian lain yang dilakukan oleh Avijgan et al juga menunjukan bahwa terjadi perubahan luka yang signifikan pada pasien luka kronik dengan perawatan luka menggunakan gel aloe vera dari pada perawatan luka konvensional. ${ }^{19}$ Perawatan luka menggunakan gel aloe vera dapat mengurangi durasi proses penyembuhan luka dan dapat mengurangi biaya rawat inap. Perbedaan biaya rata-rata perawatan luka dengan menggunakan gel aloe vera dengan perawatan konvensional masingmasing pasien adalah $\$ 2$ dan $\$ 10$ setiap hari $(p<$ 0,05). ${ }^{19}$ 
Studi kasus lain juga melaporkan bahwa setelah manajemen bedah dan pengobatan antibiotik tidak berhasil karena pasien mengalami insufisiensi vena setelah kecelakaan maka perawatan luka dilanjutkan dengan menggunakan gel aloe vera 2-3 kali sehari selama 58 hari. Hasilnya menunjukan perubahan yang signifikan dan gel aloe vera efektif untuk perawatan luka kronis. ${ }^{20}$

Gel aloe vera dapat merangsang proliferasi. ${ }^{21}$ Banyak penelitian yang telah menunjukkan bahwa perawatan dengan menggunakan gel aloe vera dapat mempercepat penyembuhan luka. Mannose-6-fosfat yang terkandung dalam gel aloe vera dapat meningkatkan kontraksi luka dan sintesis kolagen. ${ }^{22}$ Polisakarida dan acemannan dari gel aloe vera dapat meningkatkan proliferasi fibroblast dan produksi asam hialuronat dan hidroksiprolin dalam fibroblast, yang berperan penting dalam remodeling matriks ekstraseluler. ${ }^{23}$ Gula darah pasien terkontrol pada post-test minggu kedua (195 $\mathrm{mmHg}$ ) dan minggu ketiga (150 mmHg). Gula darah dapat mempengaruhi penyembuhan luka. Apabila kontrol glikemik baik maka akan dapat mempercepat proses penyembuhan luka, namun apabila konsentrasi gula tinggi maka akan dapat menghambat proliferasi fibroblast. ${ }^{24}$ Menurut analisis peneliti, gula darah pasien terkontrol disebabkan karena pasien mengkonsumsi Obat Hiperglikemik Oral (OHO) dan patuh mengkonsumsi OHO. Obat Hipoglikemik Oral merupakan obat penurun kadar glukosa darah yang diberikan secara oral.

Faktor lain yang mempengaruhi penyembuhan luka adalah hemoglobin. Pada post-test minggu pertama, minggu kedua sampai minggu ketiga nilai hemoglobin pasien terus mengalami peningkatan. Pada post-test minggu ke-1 (12.5 g/dl), minggu ke-2 $(12,7)$ dan minggu ke-3 (12,9). Hemoglobin juga mempengaruhi penyembuhan luka karena berfungsi untuk mengantarkan oksigen ke luka. Oksigen sangat penting dalam metabolisme sel dan produksi energi yang diperlukan untuk penyembuhan luka. Oksigenisasi dapat mencegah luka dari infeksi, menginduksi angiogenesis, meningkatkan diferensiasi keratinosit, migrasi, dan re-epitelisasi, meningkatkan proliferasi fibroblast, sintesis kolagen, dan mempercepat kontraksi luka. ${ }^{25}$
Pasien tidak merokok dan usia belum memasuki tahap lansia akhir sehingga penyembuhan luka menjadi cepat. Penelitian telah menunjukkan bahwa orang yang berusia di atas 60 tahun dapat memperlambat penyembuhan luka karena faktor yang terkait dengan perubahan fisik yang terjadi dengan usia lanjut. $^{26}$

Orang yang perokok merupakan faktor resiko yang dapat mempercepat proses penyembuhan luka. Dalam penelitian ini responden tidak merokok. Menurut penelitian yang dilakukan oleh Lane et al, pasien yang tidak merokok lebih cepat mengalami kesembuhan dari pasien yang merokok. ${ }^{27}$ Merokok dapat menyebabkan vasokontriksi dan membuat nafsu makan menjadi berkurang sehingga kekurangan vitamin B1, B6, B12 dan C. Merokok dapat menyebabkan oksigen berkurang secara signifikan yaitu 30-45 menit setiap setelah merokok dan nikotin yang terkandung dalam rokok dapat mempengaruhi aktivitas makrofag dan epiteliasi. ${ }^{28}$

\section{SIMPULAN}

Gel aloe vera efektif dalam perawatan luka ulkus diabetes. Penyembuhan sesuai perkembangan penyembuhan luka. Pemberiaan gel aloe vera selama 3 minggu dengan perawatan 2 hari sekali efektif untuk kasus ini.

\section{SARAN}

Perawatan luka dengan menggunakan gel aloe vera bermanfaat terhadap penyembuhan luka ulkus kaki diabetik, namun masih perlu dilakukan penelitian lanjutan sampai fase penyembuhan luka selesai.

\section{UCAPAN TERIMAKASIH}

Peneliti berterimakasih kepada pasien, Dinas Kesehatan Kota Padang dan Puskesmas di wilayah kerja kota Padang atas dukungan dan kerjasama yang diberikan selama penelitian berlangsung.

\section{DAFTAR PUSTAKA}

1. Rangel ÉB, Rodrigues CO, Sá JRD. Micro- and macrovascular complications in diabetes mellitus: preclinical and clinical studies. Journal of Diabetes Research. 2019;2019:1-5. 
2. Brocco E, Ninkovic S, Marin M, Whisstock C, Bruseghin M, Boschetti G, et al. Diabetic foot management: multidisciplinary approach for advanced lesion rescue. The Journal of Cardiovascular Surgery. 2018;59(5):670-84.

3. Atosona A, Larbie C. Prevalence and determinants of diabetic foot ulcers and lower extremity amputations in three selected tertiary hospitals in Ghana. Journal of Diabetes Research. 2019:1-9.

4. Baumfeld D, Baumfeld T, Macedo B, Zambelli R, Lopes F, Nery C. Factors related bto bamputation

level and wound healing in diabetic patients. Acta Ortopedica Brasileira. 2018;26(5):342-5.

5. Begur P, Frykberg RG. Prevention of lower extremity amputations. Podiatry Management [serial online]. 2017 Nov/Des; (diunduh 2 September 2019). Tersedia dari: http://www. podiatrym.com.

6. Dale BA, Denise H. Say Goodbye to Wsre of wound care management within your agency. Home Healthcare Nurse. 2011;29(7):429-40.

7. Wodash AJ. Wet-to-dry dressings do not provide moist wound healing. Journal of the American College of Clinical Wound Specialists 2014; 4(3): 63-6.

8. Selamet F, Usman AM, Pamungkas RA. Short report: the moisture balance with aloe vera gel in diabetic wound healing. International Journal Nursing and Health Services. 2018;1(1):21-3.

9. Rajeswari R, Umadevi M, Rahale CS, Pushpa R, Selvavenkadesh S, Kumar KPS, et al. Aloe vera: the miracle plant its medicinal and traditional uses in India. Journal of Pharmacognosy and Phytochemistry. 2012;1(4):118-24.

10. Malik I, Zarnigar. Aloe vera: a review of its clinical effectiveness. International Research Journal of Pharmacy. 2013;4(8):75-9.

11. Bhuvana KB, Hema NG, Patil RT. Review on aloe vera. International Journal of Advanced Research. 2014;2(3):677-91.

12. Mukherjee PK, Nema NK, Maity N, Mukherjee K, Harwansh RK. Phytochemical and therapeutic profile of aloe vera. Journal Of Natural Remedies. 2014;14(1):1-26.
13. Hekmatpou D, Merabi F, Rahzani K, Atefeh Aminiyan. The effect of Aloe vera clinical trials on prevention and healing of skin wound: a systematic review. Iranian journal of medical sciences. 2019;44(1):1-9.

14. Sussman C, Jensen BB, editor (penyunting). Wound Care - a collaborative practice manual for health professionals. Edisi ke-4. California: Lippincott Williams \& Wilkins; 2012.

15. Widasari SG. Perawatan luka. Bogor,Jawa Barat: Yayasan Wocare Indonesia; 2017.

16. Dhivya S, Padma VV, Santhini E. Wound dressings - a review. BioMedicine. 2015;5(4): 24-8.

17. Robb WA. Clinical trial of melolin: a new nonadherent dressing. British Journal of plastic Surgery. 1961;14:47-9.

18. Avijgan M, Alinaghian M, Esfahani MH. Aloe vera gel as a traditional and complementary method for chronic skin burn: a case report. Scientific Research an Academic Publishing. 2017;7(1): 19-25.

19. Avijgan M, Kamran A, Abedini A. Effectiveness of aloe vera gel in chronic ulcers in comparison with conventional treatments. Iranian journal of medical sciences. 2016;41(3 Suppl):S30.

20. Avijgan M. Phytotherapy: an alternative treatment for non-healing ulcers. Journal of Wound Care. 2004;13(4):157-8.

21. Teplicki E, Ma Q, Castillo DE, Zarei M, Hustad AP, Chen J, et al. The effects of aloe vera on wound healing in cell proliferation, migration, and viability. Wounds. 2018;30(9):263-68.

22. Azevedo JSDJ, Julião ELD, Dantas JBL, Reis JVNA. Is aloe vera effective for wound healing? The state of the art. Journal Of Oral Diagnosis. 2019;4:1-6.

23. Radha $\mathrm{MH}$, Laxmipriya NP. Evaluation of biological properties and clinical effectiveness of aloe vera: a systematic review. Journal of Traditional and Complementary Medicine. 2015;5:21-6.

24. Berdal M. Wound healing in diabetes [dissertation]. Health Sciences Faculty of Norway University; 2017.

25. Eisenbud DE. Oxygen in wound healing nutrient, 
antibiotic, signaling molecule, and therapeutic agent. Clinics in Plastic Surgery. 2012;39(3):293310.

26. Guo S, Dipietro LA. Factors affecting wound healing. Journal of Dental Research. 2010; 89(3): 219-29.

27. Lane CA, Selleck C, Chen Y, Tang Y. The impact of smoking and smoking cessation on wound healing in spinal cord-injured patients with pressure injuries a retrospective comparison cohort study. Journal Wound Ostomy Continence Nurs. 2016;43(5):483-7.

28. Dealay C. The care of wounds: a guide for nurses. Edisi ke-3. UK: Blackwell Publishing; 2005. 